\title{
Novel Therapeutic Strategies for Solid Tumor Based on Body's Intrinsic Antitumor Immune System
}

\author{
Haifeng Duan ${ }^{a}$ \\ aBeijing Institute of Radiation Medicine, Academy of Military Medical Sciences, Beijing, China
}

\section{Key Words}

Biological immunotherapy • Antibody drugs • Immune cell therapy • Immune environment • Intrinsic antitumor immunity

\begin{abstract}
The accumulation of mutated somatic cells due to the incompetency of body's immune system may lead to tumor onset. Therefore, enhancing the ability of the system to eliminate such cells should be the core of tumor therapy. The intrinsic antitumor immunity is triggered by tumorspecific antigens (TSA) or TSA-sensitized dendritic cells (DC). Once initiated, specific antitumor antibodies are produced and tumor-specific killer immune cells, including cytotoxic $T$ lymphocytes (CTL), NK cells, and macrophages, are raised or induced. Several strategies may enhance antitumor action of immune system, such as supplying tumor-targeted antibody, activating T cells, enhancing the activity and tumor recognition of NK cells, promoting tumortargeted phagocytosis of macrophages, and eliminating the immunosuppressive myeloidderived suppressor cells (MDSCs) and Treg cells. Apart from the immune system, the removal of tumor burden still needs to be assisted by drugs, surgery or radiation. And the body's internal environment and tumor microenvironment should be improved to recover immune cell function and prevent tumor growth. Multiple microenvironment modulatory therapies may be applied, including addressing hypoxia and oxidative stress, correcting metabolic disorders, and controlling chronic inflammation. Finally, to cure tumor and prevent tumor recurrence, repairing or supporting therapy that consist of tissue repair and nutritional supplement should be applied properly.

\section{Characteristics of the solid tumors}

Solid tumor cells themselves are heterogeneous, and tumors even from the same tissue are highly different between individuals, which may be explained by differences in mutant genes, mutation sites, gene expression profiles and the activation of cell signal pathways [14]. Up to now, a variety of anti-tumor drugs have been developed to directly target genetic mutations [5-7], thereby selecting appropriate targeted drugs.
\end{abstract}




\section{Cellular Physiology Cell Physiol Biochem 2018;47:441-457 \\ \begin{tabular}{c|c|c|} 
DOI: 10.1159/000489979 & O 2018 The Author(s). Published by S. Karger AG, Basel \\
www.karger.com/cpb
\end{tabular} \\ Duan: Novel Therapeutic Strategies Based on Antitumor Immune System}

In terms of growth and metabolism, however, solid tumors are almost similar. They all present rapid proliferation, unlimited growth, and local invasion or distant metastasis. Furthermore, tumor microenvironments accompanying the development of different tumors are almost similar as well. In summary, there are four major characteristics for solid tumor microenvironment, including tissue hypoxia, oxidative stress, metabolic disturbance and chronic inflammation. Tissue hypoxia, the essential characteristic, mainly results from two aspects. The one is tumor vessels. To maintain rapid growth, tumor releases a large number of angiogenic factors to obtain more nutrition, causing abnormal vascular proliferation [8]. The other one is the fact that tumor grows fast with exuberant metabolism and rapidly consumes oxygen through anaerobic glycolysis under aerobic condition [9]. Hypoxia leads to abnormal oxygen metabolism and generates a large number of reactive oxygen species (ROS), making tumor environment in a state of oxidative stress which is another important feature of tumor microenvironment. Metabolic disturbance is the third important feature of tumor microenvironment. As mentioned above, hypoxia can result in metabolic disturbance of oxygen itself and metabolic disturbance of glucose, lipid and protein. Such disturbance includes the changes in metabolic pathway, alterations in the structure and function of metabolic enzymes, abnormal production of metabolic intermediates and/or the production of abnormal intermediates. For example, glucose not completely catabolized results in increased production of lactic acid [10]. The abnormal metabolisms, or intermediate metabolites like CA125, CA50 and CA19-9 (referred as tumor markers) are usually adopted for the screening, diagnosis and prognosis monitoring for tumors [11]. Masses of intermediate metabolites or "garbage" resulting from metabolic disturbance can also cause chronic aseptic inflammation. Thus, a vicious chain reaction is formed: tissue hypoxia oxidative stress - metabolic disturbance - chronic inflammation, which are exact the four characteristics of tumor microenvironments.

\section{Treatment methods for solid tumors}

Currently, there are four major treatment methods for solid tumors: surgery, physiotherapy, which includes radiotherapy, radiofrequency ablation and cryotherapy, chemotherapy, which includes all sorts of small molecule chemical drugs, Chinese herbal drugs and small molecular targeted drugs, and biological immunotherapy. Universally, surgery and physiotherapy belong to local treatment, while chemotherapy and immunotherapy belong to systemic treatment. Nevertheless, the primary concern of above-mentioned treatment methods is how to effectively eliminate the tumors. On the basis of a much more generalized dialectical treatment theory, strengthening the body resistance to eliminate pathogenic factors is not only through biological immunotherapy to reconstruct body's antitumor immunity, but also via cleaning "wastes" [12], repairing tissue and organ damages caused by treatment or tumor itself, destroying tumor microenvironment and intervening in psychological stress. In short, perfect treatments for tumor should include three aspects: treating tumor (consisting of the aforesaid four treatment methods), modulating microenvironment and repairing damaged tissues.

Among the four treatment methods aiming at tumors, surgery can effectively remove tumor load, but also consume body's immune cells. The number and activity of NK cells will remarkably decrease after surgery [13]. Besides, surgery can cause great traumas to the body, especially extended surgeries, such as radical operation. Traumatic environment can locally aggregate platelets, macrophages and stem cells to participate in the repairing. Minimally invasive surgery can minimize traumas which should be the main trend for surgical treatments. Additionally, a series of new approaches cooperating with surgical treatment have been explored, such as stem cell treatment with Trial overexpression and platelet therapy with coupled antibodies [14]. Radiotherapy, including X-ray, gamma cutter, helium cutter and proton heavy ion, can release or expose tumor antigen and enhance the antitumor immunity. TLR5 agonist CBLB502 [15] can effectively prevent mucosal or 


\section{Cellular Physiology Cell Physiol Biochem 2018;47:441-457 \begin{tabular}{c|c|c|} 
DOI: 10.1159/000489979 & O 2018 The Author(s). Published by S. Karger AG, Basel \\
www.karger.com/cpb
\end{tabular} \\ Duan: Novel Therapeutic Strategies Based on Antitumor Immune System}

tissue damages caused by radiotherapy, and simultaneously stimulate natural immunity of organism, particularly enhancing NK cell activity [16], so it is one of the best collocations in radiotherapy. Thermotherapy, which contains radiofrequency ablation and hot lavage treatment, can effectively destruct the immune barrier of tumors and immobilize the tertiary structure of proteins, thus retrieving antigens and making exposed tumor antigen more stable. Therefore, thermotherapy can not only cause tumor cell necrosis but also strongly enhance body's antitumor immunity, being the best treatment compatible with biological immunotherapy. Chemotherapy can effectively eliminate tumor load and destroy tumor stroma, but has great toxicity and side effects. Therefore, in order to to avoid systemic toxicity and side effects, it is better to deliver chemotherapeutic drugs locally, use them in a lower dose, or use targeted drugs. Biological immunotherapy represents the core of novel strategy for tumor treatment recently. Deep analysis of body's intrinsic antitumor immune system is the premise and foundation for scientific and rational development of tumor biological immunotherapy.

\section{Biological immunotherapy for solid tumors}

\section{Intrinsic antitumor immune system of human body}

Fig. 1 shows the intrinsic antitumor immune system of human body. Specific antigen of mutant cells, namely tumor antigen, consists of products of mutant genes, abnormal metabolism and glycosylation modification, which can be engulfed by DC cells under normal circumstances. After being processed, tumor antigen can be delivered to B cells, and induce B cells differentiate into plasmacyte, thus leading to the production of specific antibodies. These antibodies can direct NK cells to kill tumor cells selectively, which is the so-called antibody-dependent cell cytotoxicity (ADCC effect) [17], and can also guide macrophages to phagocytose tumor cells, which is the so-called antibody-dependent cell phagocytosis (ADCP effect) [18]. Meanwhile, the antigens processed by DC cells can induce the production of cytotoxic $\mathrm{T}$ lymphocytes (CTL) to selectively kill tumor cells after being directly delivered to $\mathrm{T}$ cells. The so-called CAR-T technology is a brand new therapeutic technique through the "mix and match" of T cells and tumor specific antibodies [19-21].

NK cells and macrophages are natural immune cells with high activity which do not need direct antigen stimulation, exhibiting powerful killing effect on tumors. NK cells have cytoplasm filled with a variety of active particles, like perforin, granzyme and IFN-gamma that can be quickly released to destroy tumor cells. In contrast, T cells need to be activated by antigens and thus exert a secondary or delayed killing effect on tumor. Tumor immune escape mainly refers to escape from the killing effects of NK cells and macrophages. Escaping occurs in the following two conditions: the encapsulation and camouflage of tumor antigens and the formation of natural barrier by tumor

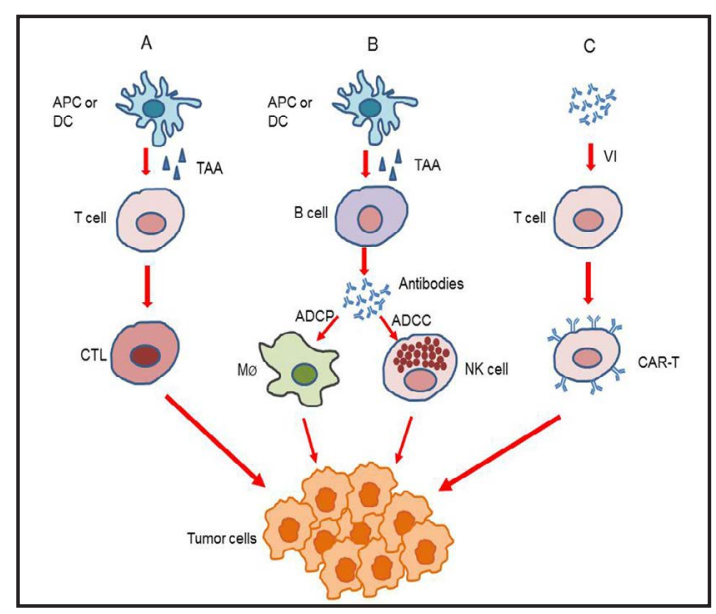

Fig. 1. Diagram for body's intrinsic anti-tumor immune system. A, Tumor-associated antigens (TAA) are presented by dendritic cells (DC) or antigen presenting cells (APC) to T cells to produce a group of tumor-specific cytotoxic T lymphocytes (CTL). B, TAA are presented by dendritic cells (DC) or antigen presenting cells (APC) to B cells to produce tumortargeted antibodies, which direct NK cells to kill tumor cells (ADCC) or guide macrophages to phagocytose tumor cells (ADCP). C, Tumor-targeted antibody is expressed on $\mathrm{T}$ cellular membrane by virus infection (VI), which is the so-called chimeric antigen receptor modified T cells (CAR-T). 


\section{Cellular Physiology Cell Physiol Biochem 2018;47:441-457 \\ \begin{tabular}{c|c|c|c|} 
DOI: 10.1159/000489979 & O 2018 The Author(s). Published by S. Karger AG, Basel \\
wwww.karger.com/cpb
\end{tabular} \\ Duan: Novel Therapeutic Strategies Based on Antitumor Immune System}

stroma. For instance, tumor cells can inhibit $\mathrm{T}$ cell activation through overexpressing its ligand PD-L1 [22]. First of all, tumors have to escape the first line of defense in the occurrence and development, namely the killing effects mediated by NK cells and the phagocytosis mediated by macrophages. Then, they positively fight against T cells and keep T cells in a "disability" state through multiple methods, including expressing ligands for T cell inhibitory receptors, collecting immunosuppressive regulatory $\mathrm{T}$ cells (Treg) and myeloid-derived suppressor cells (MDSC), consuming local oxygen, and producing numerous abnormal metabolites. However, a group of $\mathrm{T}$ cells that can recognize the tumor cells will develop in this process.

\section{Strategies for activating T cells against solid tumors}

Based on the above analyses, $\mathrm{T}$ cells have to be activated properly so as to fight with tumors, but without being facilitated for its recognition of tumor cells, which has been demonstrated by the successful application of PD-1 antibodies. Therefore, it is preferred that $\mathrm{T}$ cells should be prepared by autologous peripheral blood or tumor-infiltrating lymphocytes (TIL) due to the fact that they have memorized the tumor cells and do not need the antigen presentation by DC cells any more. Researches on DC vaccine have been carried out for many years, and in 2010, the first DC vaccine used for the treatment of prostatic cancer appeared on the market [23]. However, its effectiveness in clinic is not significant, which also proves the viewpoint presented above.

In order to activate $\mathrm{T}$ cells properly, it is necessary to understand required signals or conditions for this process. Based on existing achievements, we can make a summary that proper activation of $\mathrm{T}$ cells needs four main signals: T cell receptor (TCR) signal, costimulatory signal, inhibitory receptor signal and environmental factor signal (Fig. 2). For TCR signal, DC cells or APC cells deliver antigen information to T cells, producing TCR aiming at specific tumor antigens through gene rearrangement, which is the first step in anti-tumor $\mathrm{T}$ cell activation. Hence, the TCR signal can also be considered as tumor recognition signal. Currently, we can activate TCR via CD3 antibody (OKT3) [24]. This activation is not selective and can activate all T cells sensitized by any antigens. However, if bi-specific antibody is employed by fusing 0KT3 with specific antibody aiming at tumor antigen, it may guide T cells to kill tumor cells with excellent specificity [25]. Costimulatory signal is an elaborate regulatory mechanism developed in immune cell evolution, aiming at preventing the "simple and crude" mode of immune cell in response to stimulation, and therefore activating $\mathrm{T}$ cell properly. The costimulatory signal give T cells sufficient time to "think" before responding to stimulation and to have "flexible" space for multiple responses to the same stimulation. The most common costimulatory signals contain B7/CD28, CD137/CD137L and Cd40/CD40L $[26,27]$. Inhibitory receptor signal is a "brake" signal to prevent the excessive activation of $\mathrm{T}$ cells, which plays a key role in balancing cellular immunity [28]. Tumor cells intelligently employ this intrinsic immune regulatory mechanism to inhibit the activation of $\mathrm{T}$ cells. Whether tumor cells also suppress the costimulatory signal of T cells or APC cells and then inhibit $\mathrm{T}$ cell activation is worthy of further investigation. Environmental factor signal is the environmental condition for stimulating or inhibiting the activation of $\mathrm{T}$ cells. Relevant stimulatory elements include various immunoregulatory factors such as thymosin and interleukin, different nutrient substances such as oxygen, amino acid, vitamin, microelement, glucose and lipid, and neurotransmitters or endocrine regulation factors such as dopamine, serotonin, melatonin and norepinephrine. While inhibitory elements include hypoxia, tumor metabolites, tumor cells

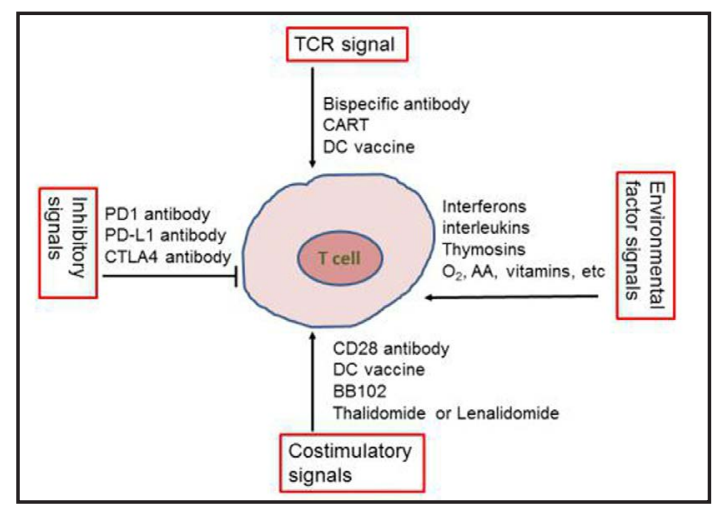

Fig. 2. Schematic diagram showing signals or conditions for activating CD8+ T cells. 


\section{Cellular Physiology Cell Physiol Biochem 2018;47:441-457 \\ \begin{tabular}{c|c|c|} 
DOI: 10.1159/000489979 & O 2018 The Author(s). Published by S. Karger AG, Basel \\
wwww.karger.com/cpb
\end{tabular} \\ Duan: Novel Therapeutic Strategies Based on Antitumor Immune System}

or immunosuppressive factors, inflammatory factors and tissue repair factors secreted by other cells in tumor tissues.

In tumor occurrence and development, under the stimulation by tumor antigens, a group of specific T cells are produced that can recognize tumor cells, thus forming TCR recognizing tumor specific antigens. Nonetheless, whether costimulatory signal is properly activated or inhibited needs specific detection. Currently, it is clear that tumor cells can make T cell inactive through expressing the ligands of its inhibitory receptors, like PD-L1 [29]. More importantly, the absence of immune activation factors or the presence of immunosuppressive factors in tumor microenvironment can lead to the loss of environmental factor signal, thus inhibiting $\mathrm{T}$ cell activation. In the presence of any signals or under any conditions, the probability of realizing complete activation of $\mathrm{T}$ cells is only $25 \%$. This reasonably explains why single application of PD-1 antibody in clinic only gains an effective rate of about 20$30 \%$. For example, according to "Science" report, of 1, 800 melanoma patients treated with PD-1 antibody, only $22 \%$ gained satisfactory results [30]. Interestingly, a recent study has found that the efficacy of PD- 1 antibody is not only dependent on PD-1 expression, but also requires the presence of CD28 costimulatory molecule [31]. Undoubtedly, such efficacy also needs the presence of TCR signal and environmental factor signal simultaneously.

In accordance with the above analyses, the following methods should be applied to solve the problem of T cell activation. Bispecific antibodies targeting both CD3 molecule and tumor specific antigen could be used to activate TCR signal and to guide T cell to kill tumor in the same time. And blocking antibodies for the inhibitory receptors, such as PD-1 and CTLA4 antibodies, can be employed to relieve inhibitory signal of T cell activation; alternatively, PD-L1 antibody could also be utilized to block the ligand of inhibitory receptor on the surface of tumor cells [32-34]. Drugs or biotechnologies are able to provide or strengthen costimulatory signals. CD28 antibody activating CD28 molecule is an important mean to strengthen costimulatory signal. TGN1412, the CD28 superactive antibody developed by German Tegenero AG Pharmaceutical Company, can strongly activate immune cells (mainly referring to T cell) of the body. Significant therapeutic effects have been achieved in animal experiments, including those on primates like monkeys. Nevertheless, TGN1412 administration already resulted in excessive activation of $\mathrm{T}$ cells in a clinical trial, with infamous "Elephant man" event as the consequence [35-37]. Thus, moderate, orderly and controllable activation of immune cells is of great importance in immunotherapy. To achieve this objective, a systematic check on the equilibrium state of different immune cells and on their proliferation and activation capacity is essential, and multiple situations containing dose-response, time-effect, targeting, and compatibility should be considered in medication. Certainly, blocking antibodies of inflammatory factors can be employed to perform precise intervention treatment for "cytokine storm" caused by excessive activation of immune cells (see detailed information in the following section of environment modulatory treatment), so as to prevent immune cells from exhaustion. Our laboratory developed a type of recombinant replication defective adenovirus BB102 carrying three genes B7-1, GM-CSF and P53 [38]. This virus can enhance costimulatory signal required for $\mathrm{T}$ cell activation through infecting tumor cells or DC cells. Preclinical study on this virus has already been completed and phase II clinical trials have been documented, making the virus a potential reagent for tumor immunotherapy. Additionally, thalidomide and its second generation drug lenalidomide, well-known as immunoregulatory drugs (IMiD), can activate T cells together with TCR signal in the absence of costimulatory signal, and strengthen $\mathrm{T}$ cell activation in the presence of costimulatory signal $[39,40]$. Immunomodulatory cytokines like interferons, interleukins and thymosins are required to create a favorable immune microenvironment for $\mathrm{T}$ cell activation [41-43]. Therefore, it is of great significance to stimulate $\mathrm{T}$ cells activation in tumor treatments via supplementing these immunomodulatory cytokines at appropriate time, or combining them with other biological drugs, such as antibodies and immune cells. For instance, a very recent study has reported that the combined application of NKTR-214 (PEG modified IL-2) can greatly enhance the antitumor efficiency of PD-1 antibody [44]. 


\section{Cellular Physiology Cell Physiol Biochem 2018;47:441-457 \\ and Biochemistry Published online: May 24, $2018 \quad$\begin{tabular}{l|l} 
DOI: 10.1159/000489979 & $\begin{array}{l}\text { (c) } 2018 \text { The Author(s). Published by S. Karger AG, Basel } \\
\text { www.karger.com/cpb }\end{array}$
\end{tabular} \\ Duan: Novel Therapeutic Strategies Based on Antitumor Immune System}

Antitumor strategies to enhance the activity and tumor recognition of NK cells

NK cell, found in 1973, is also called large granular lymphocyte in early stage because its cytoplasm is full of particles [45]. It can be assumed that NK cells are immune cells that have endocrine functions, because they have the functions of substance storage and rapid release like neuroendocrine cells, such as synapse, pancreatic islet beta cells and adrenocortical cells. A variety of active substances such as granzyme, perforin, IFN-gamma and TNF-alpha are stored in NK cells. When NK cells are stimulated and activated, these particles will be rapidly released, just as the insulin is largely released from beta cells after meals. Similar to endocrine cells, NK cell activity is also governed by neurotransmitter or endocrine hormone. When people are tense and anxious or in a stress state, their bodies will secrete a large amount of glucocorticoids. This stress response can cause a rapid decrease in NK cell activity. For example, brief mental strain can dramatically reduce NK cell activity in killing tumor cells, and 3 days are the minimum for the activity to return normal level. Prolonged mental depression or tension requires even a longer time [46]. Therefore, the NK cell activity can be improved via providing an enriched environment, keeping cheerful mood or controlling patient's mood by medication, such as antidepressant and nerve stimulant. NK cells with strong activity, together with macrophages, form the first line of immune barrier to prevent tumorigenesis. In tumor occurrence and development, tumor cells can disguise themselves through wrapping or hiding tumor antigens so as to escape the attack from NK cells in early stage. When tumor microenvironment establishes, NK cells cannot be fully activated under the influences of various factors. Consequently, two major problems on NK cells need to be solved in tumor treatment: promoting the capability of NK cells to recognize tumor cells and improving body's internal environment to increase the activity of NK cells.

In detail, methods should include the following aspects. Allogeneic NK cells, such as cord blood NK cells, relative or unrelated individual NK cells should be used to solve the problem that autologous NK cells only have low activity or cannot effectively recognize autologous tumor. Epigenetic drugs or physiotherapies like radiotherapy and thermotherapy should be applied to alter tumor phenotype, exposing its antigen and promoting the ability of NK cells to identify and kill tumor cells. Intriguingly, these epigenetic or DNA-binding drugs could also stimulate immune responses that mimic those induced by viral pathogens through Toll-like receptors $[47,48]$. NK cells should be used in combination with antitumor specific antibodies, such as Erbitux, Herceptin and Mabthera, to specifically kill corresponding tumor cells through antibody-dependent cell cytotoxicity (ADCC effect). Drugs or reagents are used to enrich NK cells in tumor local tissue by changing their migratory pathway, and then guide them to kill tumor cells in an indirect way. The distribution of NK cells in different tissues and organs are regulated by different signal molecules $[49,50]$. We can modulate different signal pathways to accumulate NK cells in different tissues and organs, and then direct them to kill tumors in targeted organ. For instance, CBLB502, the agonist of TLR5, not only enhances the NK cell activity, but also mobilizes NK cells to the liver, which make it more important in the treatment of hepatocellular carcinoma [51]. Sphingosine kinase (SPK), its catalytic substrate 1-sphingosine1-phosphate (S1P) and five receptors of S1P (S1P1-5) constitute a complex signal network that plays a key role in regulating the distribution of NK cells and T cells in tissues and blood [52-54]. For example, the reduction of S1P1 can inhibit T cell migration and keep the latter in lymph node to obtain sufficient time for the interaction with DC, thereby promoting the activation and proliferation of antigen specific $\mathrm{T}$ cells. The up-regulation of S1P1 in newly generated effector $\mathrm{T}$ cells can make T cells rapidly emigrate from lymph node to effector site. Based on these characteristics, we can use S1P1 agonist such as FTY720 in T cell activation phase or DC tumor vaccine treatment, to prolong the interaction time between $\mathrm{T}$ cell and DC, enhancing the effect of tumor vaccine. Alternatively, we can use S1P1 agonists to keep $\mathrm{T}$ cell in lymph node in the treatment of lymphoma, producing a relatively targeted killing effect on lymphoma cells.

Recent studies have shown that memory-like NK cells can be produced by pre-activating NK cells combining with cytokines (IL-12, IL-15 and IL-18). These memory-like NK cells have enhanced activity and prolonged survival time in vivo $[55,56]$. In this way, we can prepare 


\section{Cellular Physiology Cell Physiol Biochem 2018;47:441-457 \\ \begin{tabular}{c|c|c|c|} 
DOI: 10.1159/000489979 & O 2018 The Author(s). Published by S. Karger AG, Basel \\
www.karger.com/cpb
\end{tabular} \\ Duan: Novel Therapeutic Strategies Based on Antitumor Immune System}

memory-like NK cells in vitro and then transfuse them back to patients for tumor treatment. Alternatively, we can induce the production of such NK cells in vivo with cytokines to enhance the killing effects on tumor. The hypercoagulable state of tumor patient can significantly inhibit the activity of NK cells, so antiplatelet treatment is also an effective method to stimulate NK cell activity. For example, Warfarin, an anticoagulant drug, can alleviate the inhibitory effect of TAM receptor on NK cell activation, similar to T cell activation promoted by PD1 antibodies [57]. Therefore, the proliferation (IL-2, IL-12, IL-15 and IL-18), activation (CD16 antibody, Warfarin, NKG2D ligand and KIR inhibitor) and target organ migration (CBLB502, S1P5 agonist and SDF-1) of NK cells can be achieved through manipulating NK cell membrane receptors, all of which contribute to effective tumor treatment. We also can prepare bispecific antibodies through the combination of CD16 antibody with therapeutic antibody targeting tumor antigen so as to achieve the activation of NK cells and targeted killing of tumor cells. Improving and creating a microenvironment conducive to the survival, proliferation and activation of NK cells are also crucial strategies for enhancing the ability of NK cells to kill tumor cells. Detailed information is listed in the following section about environment modulatory therapy.

\section{Anti-tumor strategies for enhancing tumor-targeted phagocytosis of macrophages}

Macrophage is a type of innate immune cell originated from myelomoncytes and has special anti-tumor effects. Different from T cells and NK cells which can kill or destroy tumor cells, macrophages can directly "eat up" tumor cells or their debris and process tumor antigens. Firstly, the processed tumor antigens are submitted to T cells to induce a group of tumor-memory effector T cells. Secondly, the ingested substances of tumor cells will be then given back to the body. In contrast, tumor cells which are largely destroyed by $\mathrm{T}$ cells and NK cells may lead to "cytokine release syndrome (CRS)" or "oncolytic response". Therefore, it is of great significance to arouse tumor phagocytosis of macrophages. In one sense, tumor cells have some characteristics similar to macrophages. For instance, tumor cells can directly engulf normal cells or cell debris generated by necrotic normal cells. In this way, the nutrition and energy of normal cells can be "absorbed" by tumor cells whose growth may be accelerated at the expense of body consumption. If macrophages could be aroused for targeted phagocytosis of tumor cells, the energy and substances absorbed by tumor cells may be given back to human body, thus achieving a perfect tumor treatment effect. In addition to phagocytosis, macrophages may also play a role in antigen presenting and in the promotion of inflammatory responses, angiogenesis and tissue healing [5860]. Like other immune cells, macrophages have many types of receptors on their surface, including cytokine receptors, scavenger receptors, TLRs, and Fc receptors [61], which may receive different signals and display different functions. Macrophages have dual effects on tumor growth, which are affected by the signals. Generally, macrophages are classified into two kinds, classically activated (M1) and selectively activated (M2), showing killing and promoting effects on tumor cells, respectively [62]. M1 and M2 may achieve mutual transformation under the impacts of environmental signals.

To arouse tumor-targeted phagocytosis by macrophages, two key problems need to be resolved: how to change the phenotype of tumor cells and then promote the capability of macrophages to recognize and devour them, and how to transform M2 macrophages, namely tumor-associated macrophages (TAM), into tumor-killing M1 macrophages. The followings are some measures to solve these problems. A combined application of anti-tumor antibodies and macrophages mediated by Fc receptors may promote the engulfment effect of macrophages on tumor cells, which is the so-called antibody-dependent cell phagocytosis (ADCP effect). CD47 highly expressed by tumor cells can interact with signal regulatory protein- $\alpha$ (SIRP $\alpha$ ) on the surface of macrophages and deliver a "Do not eat me" signal to them to prevent tumor cells from be engulfed [63]. Hence, CD47-targeted antibody can be used to prevent CD47-SIRP $\alpha$ interaction, and then promote the phagocytosis effect of macrophages on tumor cells [64]. Epigenetic drugs [65], cytoxic drugs [66], and physical therapies, such as radiotherapy and thermal therapy, can be applied to change the phenotype of tumor cells 


\section{Cellular Physiology Cell Physiol Biochem 2018;47:441-457 \\ \begin{tabular}{c|c|c|} 
DOI: 10.1159/000489979 & O 2018 The Author(s). Published by S. Karger AG, Basel \\
wwww.karger.com/cpb
\end{tabular} \\ Duan: Novel Therapeutic Strategies Based on Antitumor Immune System}

and expose tumor antigens, thus making macrophages more effectively in recognize and engulf tumor cells. In addition, using the agonists of TLRs or cytokines (IL-2, IFN-gamma, TNF-alpha and histidine-rich glycoprotein) [67-70] may be another way to promote the transformation of M2 macrophages into M1 type or the tumor phagocytosis.

\section{Anti-tumor strategy via targeting immunosuppressive MDSC and Treg cells}

Body's immune system has complicated balance-regulatory mechanisms. To prevent the activation of the immune system, cellular inhibitory receptors and immunosuppressive cells are evolved. That is, a balance among immune cells can be achieved through mutual restriction of inhibitory and activating receptors or different types of immune cells. Tumor cells can intelligently employ these negatively regulatory mechanisms to inhibit anti-tumor immunity of the body. As described above, tumor cells can express ligands to suppress $\mathrm{T}$ cells. In addition, tumor cells can also inhibit the activity of effector immune cells by recruiting two important types of immunosuppressive cells, namely specific inhibitory Treg cells [71] and nonspecific myeloid-derived suppressor cells (MDSCs) [72]. Different from Treg cells, MDSCs are a group of nonspecific immature myeloid immune cells [73, 74]. "Birds of a feather flock together", these immature myeloid immune cells are similar to tumor cells in terms of primitiveness and immaturity, and thus can be recruited into tumor tissues to form an immunosuppressive microenvironment favorable for tumor growth. Generally, immunosuppressive effects of these inhibitory immune cells are shown in the following aspects. Firstly, they can cause an inability state of killing T cells through highly expressing arginase 1 to decompose L-arginine [75-77]. Secondly, they generate a large amount of oxygen free radicals that can cause conformational alteration or the disruption of membrane receptors of killing immune cells, leading to ineffective identification of tumor antigens (conformational alteration or disruption of TCR), ineffective activation (conformational alteration or disruption of IL-2R), and/or hindered migration (conformational alteration or disruption of CCR2) $[78,79]$. Thirdly, they secrete negative immuneregulatory factors, such as IL-10, and TGF-beta, to inhibit the activity or migratory ability of killing immune cells [80, 81].

The following anti-tumor strategies may be adopted to target these inhibitory immune cells. The blocking antibody or reagent of such factors as M-CSF can be used to interfere with the CCL2-CCR2 interactions, thus inhibiting the migration of immunosuppressive cells to tumor tissues. Chemical drugs can be applied to kill or remove inhibitory immune cells in tumor microenvironment. Immunoregulatory factors can be assumed to promote the proliferation and activation of killing immune cells. Differentiation inducers can be utilized to induce MDSC maturation, or the means can be taken to improve local environment.

\section{Tumor microenvironment modulatory therapy}

The purpose of tumor microenvironment modulatory therapy is to disrupt the microenvironment of tumor tissues and improve body's internal environment, thus generating suitable environment signals for the activation and proliferation of killing immune cells, and providing favorable conditions for stem cells to rapidly repair damaged tissues. Tissue hypoxia, oxidative stress, metabolic disorders, and chronic inflammation are the main characteristics of tumor microenvironment. Tumor microenvironment modulatory therapy refers to treatments directing at these characteristics, as well as improving immune environment via providing a variety of immunoregulatory factors. Traditional Chinese medicine may play an especial role in environment modulatory therapy. It considers the blood stasis as the major etiology of tumorigenesis, and one major approach for tumor treatment is to promote blood circulation and dissipate blood stasis, thus improving local hypoxia. For example, flavonoid as one component of traditional Chinese medicine is a powerful antioxidant that may antagonize local oxidative stress of tumor cells [82, 83]. 


\section{Cellular Physiology Cell Physiol Biochem 2018;47:441-457 \\ \begin{tabular}{ll|l} 
DOI: 10.1159/000489979 & and Biochemistry 2018 The Author(s). Published by S. Karger AG, Basel \\
Published online: May 24, 2018 & \begin{tabular}{l} 
www.karger.com/cpb \\
\cline { 2 - 3 }
\end{tabular}
\end{tabular} \\ Duan: Novel Therapeutic Strategies Based on Antitumor Immune System}

\section{Strategies for correcting hypoxia and oxidative stress}

In addition, hypoxia may also be corrected by normalizing abnormal tumor vessels [84]. For rapid growth, tumor cells often secrete a large number of angiogenic growth factors including vascular endothelial growth factor (VEGF), placental growth factor (PIGF) and angiogenin $[85,86]$. These factors will promote the abnormal growth of tumor vessels that contribute to the formation of hypoxic microenvironment. In 1970s, Folkman found that the proliferation of tumor cells was achieved through angiogenesis [87], and inferred that "starving" tumor cells by inhibiting tumor angiogenesis could be one of tumor treatment strategies. Based on this concept, a series of drugs have been designed to inhibit tumor angiogenesis, including bevacizumab (anti-VEGF antibody) and endostar [88, 89]. However, these drugs did not show satisfactory efficacy [90]. This phenomenon may be caused by unreasonable application of the drugs that greatly disrupt tumor vessels, aggravate local tissue hypoxia and destroy local anti-tumor immunity. Damaged tumor vessels can not delivery drugs to tumor sites, thus indirectly assisting the growth and metastasis of tumor cells. Under the treatment with anti-angiogenic drugs, paraplastic vessels of tumors will firstly become normalized (reasonable therapy) and then transform into abnormally atrophy vessels (over-treatment). For instance, a study indicated that anti-angiogenic treatment with bevacizumab for once may transform paraplastic vessels into normalized ones for about 12 days [91]. It is critical to transform tumor vessels into normalized state in anti-angiogenic treatment. To this end, the dosage, intensity, and timing of the treatment should be strictly controlled. The normalization of tumor vessels can alleviate local hypoxia, activate effector immune cells, and make anti-tumor drugs reach tumor sites to increase drug concentration in local positions. Therefore, proper anti-angiogenic treatment should be applied in combination with chemotherapy or anti-tumor immunotherapy [92].

\section{Treatment strategies for correcting metabolic disorders}

Because of hypoxic environment and rapid growth, the local substance metabolism of tumor tissues is in an abnormal state, which manifests as significantly-increased levels and activity of multiple enzymes which mainly consist of those degrading extracellular matrix and participating in the metabolism of glucose, lipid and protein, redox metabolism and the regulation of signaling pathways. In tumor cells, anaerobic glycolysis metabolism occurs under aerobic conditions and two key enzymes pyruvate kinase and alpha enolase involved in this process are abnormal. The pyruvate kinase is M2 subtype in tumor cells, which is different from in normal tissues [93]. Alpha enolase can be ectopically expressed on the cell membrane as the receptor for plasminogen to promote tumor metastasis [94]. Antimetabolite agents such as metformin and glimepiride can be used to correct the abnormal metabolism of tumor cells [95-98]. Extracellular matrix degrading enzymes or tissue digestive enzymes including urokinase, matrix metalloproteinase, cathepsin, and plasmin can not only promote tumor metastasis by degrading matrixes, but also may destroy antibody or cytokine antitumor drugs. Therefore, controlling the activity of these enzymes may be a useful strategy for tumor treatment and metastasis prevention. An antibody-like molecule has been created via using the extracellular region of tumor endothelial marker 8 (TEM8) and the Fc segment of human IgG1 antibody (TEM8 $8^{\text {ext }}$-Fc), which has been shown a powerful anti-tumor activity via inhibiting angiogenesis [99]. Subsequent studies indicate that this protein may block the activity of urokinase. Since a remarkable elevation of urokinase has been observed in

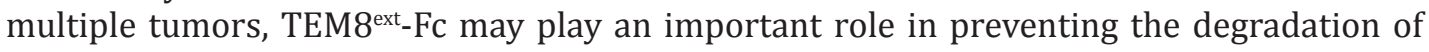
tumor stroma. Of course, for some tumors with hard texture, anti-fibrosis drugs containing hepatocyte growth factor (HGF) may also be introduced to prevent the formation of tumor stroma, destroy the tumor immunologic barrier, and enhance the effect of antitumor immunotherapy. Dipeptidylpeptidase 4 (DPP4) can not only elevate blood sugar by degrading GLP-1, but also inhibit the migration of killing T cells towards tumor location via degrading CXCL10. Therefore, its inhibitor sitagliptin, a drug for the treatment of metabolic diseases, can significantly improve anti-tumor immunity [100]. As an "energy currency", ATP releases energy through hydrolyzing phosphate radical. The metabolism of tumors is 


\section{Cellular Physiology Cell Physiol Biochem 2018;47:441-457 \\ \begin{tabular}{c|c} 
DOI: 10.1159/000489979 & O 2018 The Author(s). Published by S. Karger AG, Basel \\
www.karger.com/cpb
\end{tabular} \\ Duan: Novel Therapeutic Strategies Based on Antitumor Immune System}

active and needs a lot of energy, leading to a local hypoxia condition and excessive hydrolysis of ATP by CD39 and CD73 overexpressed by Treg cells, which result in the production of large amounts of adenosine [101-103]. High concentrations of adenosine will then combine with its receptors A2AR and A2BR to inhibit the activation of TCR signals, thus weakening the killing effects of $\mathrm{T}$ cells on the tumor, which is known as hypoxia-adenosinergic immunosuppression $[104,105]$. In addition, abnormal metabolic enzymes in tumor tissues also include enzymes generating proinflammatory factors or degrading specific amino acids. For example, immunosuppressive cells MDSCs and TAM in tumor tissues can highly express arginase 1 that can degrade L-arginine needed in the activation of killing T cells $[75-77,106]$.

\section{Treatment strategies for controlling chronic inflammation}

Tumor microenvironment is complicated and has numerous different types of inflammatory factors. These factors may lead to inflammatory responses such as local edema, pain and fever via stimulating angiogenesis and increasing vascular permeability. Besides, they result in weakened anti-tumor immunity and fastened tumor growth through recruiting immunosuppressive cells. Since inflammatory responses may also resist tumor growth, we should keep good control of anti-inflammatory treatment just as in anti-angiogenic tumor therapy. We propose that precise anti-inflammatory treatment should be conducted on the basis of measured levels of these inflammatory factors. Generally, inflammatory factors can be classified into three classes: cytokines, such as TNF-alpha, IL-6, IL-17A, and IL-1beta; abnormally increased metabolic enzymes or products, such as IDO, NO, and PGE2; and cellular contents released by dead or necrotic cells, such as mitochondrial components and nucleic acid fragments. For the first class, specific blocking antibodies for single inflammatory factor [107-109] or double-blocking antibodies that can block two inflammatory factors simultaneously may be applied. For the second class, specific enzyme inhibitors for IDO, COX2, and iNOS can be used to inhibit the enzyme activity and reduce the generation of inflammatory metabolites [110-112]. For the third class, proper measures should be taken to enhance the phagocytosis of macrophages to clean up these cellular contents and relieve inflammatory responses.

\section{Supportive treatment focusing on tissue repairing}

Rapid tumor growth and conventional anti-tumor therapies will inevitably cause injuries to the structure and function of normal tissues. In addition, the tumor occurrence is also closely related with tissue injury, because tissue injury activates mutated genes and causes inflammatory responses, which are the essential requirements for tumor occurrence. Once tumor occurs, it will be difficult for the damages on normal tissues to be healed, which is why tumor is considered as an incurable wound [113]. It is revealed that the incidence rate of tumor is closely correlated with age, with an exponential growth among individuals over 40 years old in both women and men [114]. The elderly population has a high incidence rate in developing solid tumors, like lung, liver, and gastrointestinal tumors, so solid tumors have become one of the commonly encountered senile diseases [115]. This phenomenon may be explained by reduced stem cell pool and accordingly decreased ability to repair injured tissues in elderly people. Thus, supportive treatment focusing on tissue repair not only can strengthen body's resistance to invasive tumor therapy, but also represents a key part for curing tumors.

Repairing therapy should consist of tissue repair and nutritional supplement. First of all, gastrointestinal mucous membranes need to be repaired so as to promote food digestion and absorption. Secondly, liver functions should be improved to facilitate metabolism of energy and substances. Thirdly, the functions of heart, lung and kidney should be maintained to improve the insufficiency of both blood and vital energy. Fourthly, hematopoietic and immune systems need to be healed to enhance anti-tumor immunity. Finally, neuropsychology should be rehabilitated via emotion management, pain control and spiritual compensation [116]. Thus, giving psychological guidance and spiritual concern and rational administrating drugs could be recommended, such as antidepressants, anticonvulsants, tranquillizers, agents 


\section{Cellular Physiology Cell Physiol Biochem 2018;47:441-457 \begin{tabular}{cc|c} 
DOI: 10.1159/000489979 & O 2018 The Author(s). Published by S. Karger AG, Basel \\
www.karger.com/cpb
\end{tabular} \\ Duan: Novel Therapeutic Strategies Based on Antitumor Immune System}

against psychiatric disorders [117], anti-melancholies or vasodilators. Application of nerve growth factor (NGF) may also be useful for repairing nerve injuries and improving mental states. Stem cells can differentiate into different tissue cells and secrete large amounts of growth factors or nutritional factors, which can improve local microenvironment and tissue repair. Therefore, stem cells may be one of the best measures for tumor supportive treatment. However, stem cells may also promote tumor growth. Therefore, it is of most importance to prevent tumor growth in repairing therapy using stem cells. We found that mesenchymal stem cells (MSCs) may have two opposite phenotypes of inhibiting and promoting tumor growth. TLR5 positive is one of the major characteristics of the phenotype in inhibiting tumor growth. Therefore, preprocessing or gene-modifying MSCs using TLR5 or the 3TSR segment of thrombospondin-1 combined with S-TRAIL may be a good approach for MSCbased tumor therapy, thus promoting tissue repair and inhibiting tumor growth [118].

\section{Conclusion and advantages of novel therapeutic strategy}

Based on the above elaborations about tumor treatment, we propose a novel strategy for comprehensive treatment of solid tumors, with antibody drug and cell therapeutic technique as the core, in combination with surgery, radiotherapy, chemotherapy. Centered on intrinsic anti-tumor immune mechanism and tissue-repairing system of human body, this strategy will be a integration of considerations on: (1) different types of immune cells and stem cells, including T cells, NK cells, NKT cells, macrophages, hematopoietic stem cells, and mesenchymal stem cells, (2) antibody drugs, such as tumor-targeted, broad-specificity, bispecific, T cell activation, NK cell activation, and macrophage activation antibodies as well as blocking antibodies for inflammatory factors, (3) immunoregulatory factors, including thymosins, interleukins, interferons, lenalidomide, and TLR agonists like CBLB502, and (4) environment modulatory drugs, such as anti-angiogenic agents, antioxidants, antimetabolites, and anti-inflammatory agents. Based on this strategy, a safe, scientific, reasonable, and effective tumor treatment scheme can be made, with the hope that solid tumors can be radically cured in the future.

In general, our novel strategy has four advantages. Firstly, multiple steps of treatment with antibodies and immune cells can induce the generation of anti-tumor memory immune cells or activate the existing ones so as to establish the long-term and systemic anti-tumor immunity. Secondly, multiple measures are crossly applied for all-around targeted clearance of tumor cells in different levels, especially for residual tumor stem cells. Thirdly, the theories of activating blood to remove stasis, eliminating pathogen to thoroughly improve body's internal environment and remove the "soil" that breeds tumor. Lastly, the strategy has the characteristics of both universality, such as improving the body's internal environment and destroying tumor microenvironment, and individualization, like the application of targeted drugs and patient's immune cells.

\section{Acknowledgements}

The author greatly appreciates the support from Dr. Peiliang Geng, Jing Xie and Binghua Xue.

\section{Disclosure Statement}

The author declares to have no competing interests.

\section{References}

\footnotetext{
1 Punt CJ, Koopman M, Vermeulen L: From tumour heterogeneity to advances in precision treatment of colorectal cancer. Nat Rev Clin Oncol 2017;14:235-246.
} 


\section{Cellular Physiology Cell Physiol Biochem 2018;47:441-457 \begin{tabular}{l|l} 
DOI: 10.1159/000489979 & O 2018 The Author(s). Published by S. Karger AG, Basel \\
www.karger.com/cpb
\end{tabular}}

2 Ponder BA: Cancer genetics. Nature 2001;411:336-341.

3 You JS, Jones PA: Cancer genetics and epigenetics: two sides of the same coin? Cancer Cell 2012;22:9-20.

4 Stoeltzing 0, Meric-Bernstam F, Ellis LM: Intracellular signaling in tumor and endothelial cells: The expected and, yet again, the unexpected. Cancer Cell 2006;10:89-91.

5 Gill H, Leung AY, Kwong YL: Molecularly targeted therapy in acute myeloid leukemia. Future Oncol 2016;12:827-838..

6 Punt CJ, Koopman M, Vermeulen L: From tumour heterogeneity to advances in precision treatment of colorectal cancer. Nat Rev Clin Oncol 2017;14:235-246.

7 Zhang H: Three generations of epidermal growth factor receptor tyrosine kinase inhibitors developed to revolutionize the therapy of lung cancer. Drug Des Devel Ther 2016;10:3867-3872.

-8 Huang Y, Goel S, Duda DG, Fukumura D, Jain RK: Vascular normalization as an emerging strategy to enhance cancer immunotherapy. Cancer Res 2013;73:2943-2948.

-9 Pavlides S, Whitaker-Menezes D, Castello-Cros R, Flomenberg N, Witkiewicz AK, Frank PG, Casimiro MC, Wang C, Fortina P, Addya S, Pestell RG, Martinez-Outschoorn UE, Sotgia F, Lisanti MP: The reverse Warburg effect: aerobic glycolysis in cancer associated fibroblasts and the tumor stroma. Cell Cycle 2009;8:39844001.

10 Kennedy KM, Dewhirst MW: Tumor metabolism of lactate: the influence and therapeutic potential for MCT and CD147 regulation. Future Oncol 2010;6:127-148.

11 Szymendera JJ: Clinical usefulness of three monoclonal antibody-defined tumor markers: CA 19-9, CA 50, and CA 125 Tumour Biol 1986;7:333-342

12 Salami J, Crews CM: Waste disposal-An attractive strategy for cancer therapy. Science 2017;355:1163-1167

13 Pollock RE, Lotzova E, Stanford SD: Surgical stress impairs natural killer cell programming of tumor for lysis in patients with sarcomas and other solid tumors. Cancer 1992;70:2192-2202.

$>14$ Chao Wang, Wujin Sun, Yanqi Ye, Quanyin Hu, Hunter N. Bomba\& Zhen Gu: In situ activation of platelets with checkpoint inhibitors for post-surgical cancer immunotherapy. Nature biomedical engineer 2017.

15 Burdelya LG, Krivokrysenko VI, Tallant TC, Strom E, Gleiberman AS, Gupta D, Kurnasov OV, Fort FL, Osterman AL, Didonato JA, Feinstein E, Gudkov AV: An agonist of toll-like receptor 5 has radioprotective activity in mouse and primate models. Science 2008;320:226-230.

16 Yang H, Brackett CM, Morales-Tirado VM, Li Z, Zhang Q, Wilson MW, Benjamin C, Harris W, Waller EK, Gudkov AV, Burdelya LG, Grossniklaus HE: The Toll-like receptor 5 agonist entolimod suppresses hepatic metastases in a murine model of ocular melanoma via an NK cell-dependent mechanism. Oncotarget 2016;7:2936-2950.

17 Seidel UJ, Schlegel P, Lang P: Natural killer cell mediated antibody-dependent cellular cytotoxicity in tumor immunotherapy with therapeutic antibodies. Front Immunol 2013;4:76.

18 Sockolosky JT, Dougan M, Ingram JR, Ho CC, Kauke MJ, Almo SC, Ploegh HL, Garcia KC: Durable antitumor responses to CD47 blockade require adaptive immune stimulation. Proc Natl Acad Sci USA 2016;113:E2646-E2654.

19 Grupp SA, Kalos M, Barrett D, Aplenc R, Porter DL, Rheingold SR, Teachey DT, Chew A, Hauck B, Wright JF, Milone MC, Levine BL, June $\mathrm{CH}$ : Chimeric antigen receptor-modified T cells for acute lymphoid leukemia. $\mathrm{N}$ Engl J Med 2013;368:1509-1518.

-20 Porter DL, Levine BL, Kalos M, Bagg A, June CH: Chimeric antigen receptor-modified T cells in chronic lymphoid leukemia. N Engl J Med 2011;365:725-733.

21 Maude SL, Frey N, Shaw PA, Aplenc R, Barrett DM, Bunin NJ, Chew A, Gonzalez VE, Zheng Z, Lacey SF, Mahnke YD, Melenhorst JJ, Rheingold SR, Shen A, Teachey DT, Levine BL, June CH, Porter DL, Grupp SA: Chimeric antigen receptor T cells for sustained remissions in leukemia. N Engl J Med 2014;371:1507-1517.

22 Chen DS, Mellman I: Elements of cancer immunity and the cancer-immune set point. Nature 2017;541:321330.

23 Kantoff PW, Higano CS, Shore ND, Berger ER, Small EJ, Penson DF, Redfern CH, Ferrari AC, Dreicer R, Sims RB, Xu Y, Frohlich MW, Schellhammer PF; IMPACT Study Investigators: Sipuleucel-T immunotherapy for castration-resistant prostate cancer. N Engl J Med 2010;363:411-422.

-24 Van Wauwe JP, De Mey JR, Goossens JG: OKT3: a monoclonal anti-human T lymphocyte antibody with potent mitogenic properties. J Immunol 1980;124:2708-2713.

25 Zhang X, Yang Y, Fan D, Xiong D: The development of bispecific antibodies and their applications in tumor immune escape. Exp Hematol Oncol 2017;6:12. 


\section{Cellular Physiology Cell Physiol Biochem 2018;47:441-457 \begin{tabular}{l|l} 
DOI: 10.1159/000489979 & and Biochemistry \\
Published online: May 24, 2018 & $\begin{array}{l}\text { O } 2018 \text { The Author(s). Published by S. Karger AG, Basel } \\
\text { www.karger.com/cpb }\end{array}$
\end{tabular}}

Duan: Novel Therapeutic Strategies Based on Antitumor Immune System

26 Croft M: Co-stimulatory members of the TNFR family: keys to effective T-cell immunity? Nat Rev Immunol 2003;3:609-620.

27 Ford ML, Adams AB, Pearson TC: Targeting co-stimulatory pathways: transplantation and autoimmunity. Nat Rev Nephrol 2014;10:14-24.

28 Ravetch JV, Lanier LL: Immune inhibitory receptors. Science 2000;290:84-89.

29 Dong H, Strome SE, Salomao DR, Tamura H, Hirano F, Flies DB, Roche PC, Lu J, Zhu G, Tamada K, Lennon VA, Celis E, Chen L: Tumor-associated B7-H1 promotes T-cell apoptosis: a potential mechanism of immune evasion. Nat Med 2002;8:793-800.

-30 Couzin-Frankel J: Breakthrough of the year 2013. Cancer immunotherapy. Science 2013;342:1432-1433.

-31 Kamphorst AO, Wieland A, Nasti T, Yang S, Zhang R, Barber DL, KoniecznyBT,Daugherty CZ, Koenig L, Yu K, Sica GL, Sharpe AH, Freeman GJ, Blazar BR, TurkaLA, Owonikoko TK, Pillai RN, Ramalingam SS, Araki $\mathrm{K}$, Ahmed R: Rescue of exhausted CD8 T cells by PD-1-targeted therapies is CD28-dependent. Science 2017;355:1423-1427.

-32 Topalian SL, Hodi FS, Brahmer JR, Gettinger SN, Smith DC, McDermott DF, Powderly JD, Carvajal RD, Sosman JA, Atkins MB, Leming PD, Spigel DR, Antonia SJ, Horn L, Drake CG, Pardoll DM, Chen L, Sharfman WH, Anders RA, Taube JM, McMiller TL, Xu H, Korman AJ, Jure-Kunkel M, Agrawal S, McDonald D, Kollia GD, Gupta A, Wigginton JM, Sznol M: Safety, activity, and immune correlates of anti-PD-1 antibody in cancer. N Engl J Med 2012;366:2443-2454.

-33 Sznol M, Chen L: Antagonist antibodies to PD-1 and B7-H1 (PD-L1) in the treatment of advanced human cancer. Clin Cancer Res 2013;19:1021-1034.

-34 Apolo AB, Infante JR, Balmanoukian A, Patel MR, Wang D, Kelly K, Mega AE, Britten CD, Ravaud A, Mita AC, Safran H, Stinchcombe TE, Srdanov M, Gelb AB, Schlichting M, Chin K, Gulley JL: Avelumab, an AntiProgrammed Death-Ligand 1 Antibody, In Patients With Refractory Metastatic Urothelial Carcinoma: Results From a Multicenter, Phase Ib Study. J Clin Oncol 2017:JC02016716795.

-35 Horvath C, Andrews L, Baumann A, Black L, Blanset D, Cavagnaro J, Hastings KL, Hutto DL, MacLachlan TK, Milton M, Reynolds T, Roberts S, Rogge M, Sims J, Treacy G, Warner G, Green JD: Storm forecasting: additional lessons from the CD28 superagonist TGN1412 trial. Nat Rev Immunol 2012;12:740; author reply 740.

36 Schraven B, Kalinke U: CD28 superagonists: what makes the difference in humans? Immunity 2008;28:591595.

-37 Hansen S, Leslie RG: TGN1412: scrutinizing preclinical trials of antibody-based medicines. Nature 2006;441:282.

38 Ren SP, Wu CT, Huang WR, Lu ZZ, Jia XX, Wang L, Lao MF, Wang LS: Adenoviral-mediated transfer of human wild-type p53, GM-CSF and B7-1 genes results in growth suppression and autologous anti-tumor cytotoxicity of multiple myeloma cells in vitro. Cancer Immunol Immunother 2006;55:375-385.

-39 Haslett PA, Corral LG, Albert M, Kaplan G: Thalidomide costimulates primary human T lymphocytes, preferentially inducing proliferation, cytokine production, and cytotoxic responses in the CD8+ subset. J Exp Med 1998;187:1885-1892.

-40 LeBlanc R, Hideshima T, Catley LP, Shringarpure R, Burger R, Mitsiades N, Mitsiades C, Cheema P, Chauhan D, Richardson PG, Anderson KC, Munshi NC: Immunomodulatory drug costimulates T cells via the B7-CD28 pathway. Blood 2004;103:1787-1790.

-41 Boyman 0, Purton JF, Surh CD, Sprent J: Cytokines and T-cell homeostasis. Curr Opin Immunol 2007;19:320-326.

-42 Akdis M, Aab A, Altunbulakli C, Azkur K, Costa RA, Crameri R, Duan S, Eiwegger T, Eljaszewicz A, Ferstl R, Frei R, Garbani M, Globinska A, Hess L, Huitema C, Kubo T, Komlosi Z, Konieczna P, Kovacs N, Kucuksezer UC, Meyer N, Morita H, Olzhausen J, O’Mahony L, Pezer M, Prati M, Rebane A, Rhyner C, Rinaldi A, Sokolowska M, Stanic B, Sugita K, Treis A, van de Veen W, Wanke K, Wawrzyniak M, Wawrzyniak P, Wirz OF, Zakzuk JS, Akdis CA: Interleukins (from IL-1 to IL-38), interferons, transforming growth factor $\beta$, and TNF- $\alpha$ : Receptors, functions, and roles in diseases. J Allergy Clin Immunol 2016;138:984-1010.

43 Naylor PH, Goldstein AL: Thymosin: cyclic nucleotides and T cell differentiation. Life Sci 1979;25:301-310.

44 Charych DH, Hoch U, Langowski JL, Lee SR, Addepalli MK, Kirk PB, Sheng D, Liu X, Sims PW, VanderVeen LA, Ali CF, Chang TK, Konakova M, Pena RL, Kanhere RS, Kirksey YM, Ji C, Wang Y, Huang J, Sweeney TD, Kantak SS, Doberstein SK: NKTR-214, an Engineered Cytokine with Biased IL2 Receptor Binding, Increased Tumor Exposure, and Marked Efficacy in Mouse Tumor Models. Clin Cancer Res 2016;22:680-690. 


\section{Cellular Physiology Cell Physiol Biochem 2018;47:441-457 \begin{tabular}{c|c} 
DOI: 10.1159/000489979 & O 2018 The Author(s). Published by S. Karger AG, Basel \\
www.karger.com/cpb
\end{tabular} \\ Duan: Novel Therapeutic Strategies Based on Antitumor Immune System}

45 Guillerey C, Huntington ND, Smyth MJ: Targeting natural killer cells in cancer immunotherapy. Nat Immunol 2016;17:1025-1036.

-46 Hiramoto RN, Solvason HB, Hsueh CM, Rogers CF, Demissie S, Hiramoto NS, Gauthier DK, Lorden JF, Ghanta VK: Psychoneuroendocrine immunology: perception of stress can alter body temperature and natural killer cell activity. Int J Neurosci 1999;98:95-129.

-47 Sistigu A, Yamazaki T, Vacchelli E, Chaba K, Enot DP, Adam J, Vitale I, Goubar A, Baracco EE, Remédios C, Fend L, Hannani D, Aymeric L, Ma Y, Niso-Santano M, Kepp O, Schultze JL, Tüting T, Belardelli F, Bracci L, La Sorsa V, Ziccheddu G, Sestili P, Urbani F, Delorenzi M, Lacroix-Triki M, Quidville V, Conforti R, Spano JP, Pusztai L, Poirier-Colame V, Delaloge S, Penault-Llorca F, Ladoire S, Arnould L, Cyrta J, Dessoliers MC, Eggermont A, Bianchi ME, Pittet M, Engblom C, Pfirschke C, Préville X, Uzè G, Schreiber RD, Chow MT, Smyth MJ, Proietti E, André F, Kroemer G, Zitvogel L: Cancer cell-autonomous contribution of type I interferon signaling to the efficacy of chemotherapy. Nat Med 2014;20:1301-1309.

48 Chiappinelli KB, Strissel PL, Desrichard A, Li H, Henke C, Akman B, Hein A, Rote NS, Cope LM, Snyder A, Makarov V, Budhu S, Slamon DJ, Wolchok JD, Pardoll DM, Beckmann MW, Zahnow CA, Merghoub T, Chan TA, Baylin SB, Strick R: Inhibiting DNA Methylation Causes an Interferon Response in Cancer via dsRNA Including Endogenous Retroviruses. Cell 2015;162:974-986

49 Grégoire C, Chasson L, Luci C, Tomasello E, Geissmann F, Vivier E, Walzer T: The trafficking of natural killer cells. Immunol Rev 2007;220:169-182.

50 Vivier E, Tomasello E, Baratin M, Walzer T, Ugolini S: Functions of natural killer cells. Nat Immunol 2008;9:503-510.

51 Burdelya LG, Brackett CM, Kojouharov B, Gitlin II, Leonova KI, Gleiberman AS, Aygun-Sunar S, Veith J, Johnson C, Haderski GJ, Stanhope-Baker P, Allamaneni S, Skitzki J, Zeng M, Martsen E, Medvedev A, Scheblyakov D, Artemicheva NM, Logunov DY, Gintsburg AL, Naroditsky BS, Makarov SS, Gudkov AV: Central role of liver in anticancer and radioprotective activities of Toll-like receptor 5 agonist. Proc Natl Acad Sci USA 2013;110:E1857-E1866.

52 Graeler M, Shankar G, Goetzl EJ: Cutting edge: suppression of T cell chemotaxis by sphingosine 1-phosphate. J Immunol 2002;169:4084-4087.

53 Walzer T, Chiossone L, Chaix J, Calver A, Carozzo C, Garrigue-Antar L, Jacques Y, Baratin M, Tomasello E, VivierE: Natural killer cell trafficking in vivo requires a dedicated sphingosine 1-phosphate receptor. Nat Immunol 2007;8:1337-1344.

54 Matloubian M, Lo CG, Cinamon G, Lesneski MJ, Xu Y, Brinkmann V, Allende ML, Proia RL, Cyster JG: Lymphocyte egress from thymus and peripheral lymphoid organs is dependent on S1P receptor 1 Nature 2004;427:355-360.

55 Romee R, Rosario M, Berrien-Elliott MM, Wagner JA, Jewell BA, Schappe T, Leong JW, Abdel-Latif S, Schneider SE, Willey S, Neal CC, Yu L, Oh ST, Lee YS, Mulder A, Claas F, Cooper MA, Fehniger TA: Cytokineinduced memory-like natural killer cells exhibit enhanced responses against myeloid leukemia. Sci Transl Med 2016;8:357ra123.

-56 Romee R, Schneider SE, Leong JW, Chase JM, Keppel CR, Sullivan RP, Cooper MA, Fehniger TA: Cytokine activation induces human memory-like NK cells. Blood 2012;120:4751-4760.

-57 Paolino M, Choidas A, Wallner S, Pranjic B, Uribesalgo I, Loeser S, Jamieson AM, Langdon WY, Ikeda F, Fededa JP, Cronin SJ, Nitsch R, Schultz-Fademrecht C, Eickhoff J, Menninger S, Unger A, Torka R, Gruber T, Hinterleitner R, Baier G, Wolf D, Ullrich A, Klebl BM, Penninger JM: The E3 ligase Cbl-b and TAM receptors regulate cancer metastasis via natural killer cells. Nature 2014;507:508-512.

58 Geeraerts X, Bolli E, Fendt SM, Van Ginderachter JA: Macrophage Metabolism As Therapeutic Target for Cancer, Atherosclerosis, and Obesity. Front Immunol 2017; 8:289.

59 Bosurgi L, Cao YG, Cabeza-Cabrerizo M, Tucci A, Hughes LD, Kong Y, Weinstein JS, Licona-Limon P, Schmid ET, Pelorosso F, Gagliani N, Craft JE, Flavell RA, Ghosh S, Rothlin CV: Macrophage function in tissue repair and remodeling requires IL-4 or IL-13 with apoptotic cells. Science 2017 pii: eaai8132.

60 Mantovani A, Locati M: Macrophage Metabolism Shapes Angiogenesis in Tumors. Cell Metab 2016;24:887888.

61 Mosser DM, Edwards JP: Exploring the full spectrum of macrophage activation. Nat Rev Immunol 2008;8:958-969.

62 Goswami KK, Ghosh T, Ghosh S, Sarkar M, Bose A, Baral R: Tumor promoting role of anti-tumor 


\section{Cellular Physiology Cell Physiol Biochem 2018;47:441-457 \begin{tabular}{l|l} 
DOI: 10.1159/000489979 & Ond Biochemistry 2018 The Author(s). Published by S. Karger AG, Basel \\
wublished online: May 24, 2018 & and.com/cpb
\end{tabular} \\ Duan: Novel Therapeutic Strategies Based on Antitumor Immune System}

macrophages in tumor microenvironment. Cell Immunol 2017.pii: S0008-8749(17)30061-8.

63 Zhao XW, van Beek EM, Schornagel K, Van der Maaden H, Van Houdt M, Otten MA, Finetti P, Van Egmond M, Matozaki T, Kraal G, Birnbaum D, van Elsas A, Kuijpers TW, Bertucci F, van den Berg TK: CD47-signal regulatory protein- $\alpha(\operatorname{SIRP} \alpha)$ interactions form a barrier for antibody-mediated tumor cell destruction. Proc Natl Acad Sci USA 2011;108:18342-18347.

64 Gholamin S, Mitra SS, Feroze AH, Liu J, Kahn SA, Zhang M, Esparza R, Richard C, Ramaswamy V, Remke M, Volkmer AK, Willingham S, Ponnuswami A, McCarty A, Lovelace P, Storm TA, Schubert S, Hutter G, Narayanan C, Chu P, Raabe EH, Harsh G 4th, Taylor MD, Monje M, Cho YJ, Majeti R, Volkmer JP, Fisher PG, Grant G, Steinberg GK, Vogel H, Edwards M, Weissman IL, Cheshier SH: Disrupting the CD47-SIRP $\alpha$ antiphagocytic axis by a humanized anti-CD47 antibody is an efficacious treatment for malignant pediatric brain tumors. Sci Transl Med 2017;9. pii: eaaf2968.

65 Guerriero JL, Sotayo A, Ponichtera HE, Castrillon JA, Pourzia AL, Schad S, Johnson SF, Carrasco RD, Lazo S, Bronson RT, Davis SP, Lobera M, Nolan MA, Letai A: Class IIa HDAC inhibition reduces breast tumours and metastases through anti-tumour macrophages. Nature 2017;543:428-432.

66 Yamaguchi T, Fushida S, Yamamoto Y, Tsukada T, Kinoshita J, Oyama K, Miyashita T, Tajima H, Ninomiya I, Munesue S, Harashima A, Harada S, Yamamoto H, Ohta T: Low-dose paclitaxel suppresses the induction of M2 macrophages in gastric cancer. Oncol Rep 2017.

67 Huang Y, Snuderl M, Jain RK: Polarization of tumor-associated macrophages: a novel strategy for vascular normalization and antitumor immunity. Cancer Cell 2011;19:1-2.

68 Rolny C, Mazzone M, Tugues S, Laoui D, Johansson I, Coulon C, Squadrito ML, Segura I, Li X, Knevels E, Costa S, Vinckier S, Dresselaer T, Åkerud P, De Mol M, Salomäki H, Phillipson M, Wyns S, Larsson E, Buysschaert I, Botling J, Himmelreich U, Van Ginderachter JA, De Palma M, Dewerchin M, Claesson-Welsh L, Carmeliet P: HRG inhibits tumor growth and metastasis by inducing macrophage polarization and vessel normalization through downregulation of PlGF. Cancer Cell 2011;19:31-44.

-69 Prakash H, Nadella V, Singh S, Schmitz-Winnenthal H: CD14/TLR4 priming potentially recalibrates and exerts anti-tumor efficacy in tumor associated macrophages in a mouse model of pancreatic carcinoma. Sci Rep 2016;6:31490.

-70 Feng M, Chen JY, Weissman-Tsukamoto R, Volkmer JP, Ho PY, McKenna KM, Cheshier S, Zhang M, Guo N, Gip P, Mitra SS, Weissman IL: Macrophages eat cancer cells using their own calreticulin as a guide: roles of TLR and Btk. Proc Natl Acad Sci USA 2015;112:2145-2150.

71 Oleinika K, Nibbs RJ, Graham GJ, Fraser AR: Suppression, subversion and escape: the role of regulatory T cells in cancer progression. Clin Exp Immunol 2013;171:36-45.

72 Marvel D, Gabrilovich DI: Myeloid-derived suppressor cells in the tumor microenvironment: expect the unexpected. J Clin Invest 2015;125:3356-3364.

73 Gabrilovich DI, Ostrand-Rosenberg S, Bronte V: Coordinated regulation of myeloid cells by tumours. Nat Rev Immunol 2012;12:253-268.

74 Poschke I, Kiessling R: On the armament and appearances of human myeloid-derived suppressor cells. Clin Immunol 2012;144:250-268.

-75 Rodriguez PC, Ernstoff MS, Hernandez C, Atkins M, Zabaleta J, Sierra R, Ochoa AC: Arginase I-producing myeloid-derived suppressor cells in renal cell carcinoma are a subpopulation of activated granulocytes. Cancer Res 2009;69:1553-1560.

-76 Mazzoni A, Bronte V, Visintin A, Spitzer JH, Apolloni E, Serafini P, Zanovello P, Segal DM: Myeloid suppressor lines inhibit T cell responses by an NO-dependent mechanism. J Immunol 2002;168:689-695.

-77 Gabrilovich D: Mechanisms and functional significance of tumour-induced dendritic-cell defects. Nat Rev Immunol 2004;4:941-952.

78 Nagaraj S, Gupta K, Pisarev V, Kinarsky L, Sherman S, Kang L, Herber DL, Schneck J, Gabrilovich DI: Altered recognition of antigen is a mechanism of CD8+ T cell tolerance in cancer. Nat Med 2007;13:828-835.

79 OuYang LY, Wu XJ, Ye SB, Zhang RX, Li ZL, Liao W, Pan ZZ, Zheng LM, Zhang XS, Wang Z, Li Q, Ma G, Li J: Tumor-induced myeloid-derived suppressor cells promote tumor progression through oxidative metabolism in human colorectal cancer. J Transl Med 2015;13:47.

-80 Pickup M, Novitskiy S, Moses HL: The roles of TGF $\beta$ in the tumour microenvironment. Nat Rev Cancer 2013;13:788-799. 


\section{Cellular Physiology Cell Physiol Biochem 2018;47:441-457 \begin{tabular}{c|c|c|} 
DOI: 10.1159/000489979 & O 2018 The Author(s). Published by S. Karger AG, Basel \\
www.karger.com/cpb
\end{tabular} \\ Duan: Novel Therapeutic Strategies Based on Antitumor Immune System}

-81 Rossowska J, Anger N, Kicielińska J, Pajtasz-Piasecka E, Bielawska-Pohl A, Wojas-Turek J, Duś D: Temporary elimination of IL-10 enhanced the effectiveness of cyclophosphamide and BMDC-based therapy by decrease of the suppressor activity of MDSCs and activation of antitumour immune response. Immunobiology 2015;220:389-398.

82 Alibeiki F, Jafari N, Karimi M, Peeri Dogaheh H: Potent anti-cancer effects of less polar Curcumin analogues on gastric adenocarcinoma and esophageal squamous cell carcinoma cells. Sci Rep 2017;7:2559.

83 Panda AK, Chakraborty D, Sarkar I, Khan T, Sa G: New insights into therapeutic activity and anticancer properties of curcumin. J Exp Pharmacol 2017;9:31-45.

$>84$ Jain RK: Normalizing tumor vasculature with anti-angiogenic therapy: a new paradigm for combination therapy. Nat Med 2001;7:987-989.

85 Heindryckx F, Coulon S, Terrie E, Casteleyn C, Stassen JM, Geerts A, Libbrecht L, Allemeersch J, Carmeliet P, Colle I, Van Vlierberghe H: The placental growth factor as a target against hepatocellular carcinoma in a diethylnitrosamine-induced mouse model. J Hepatol 2013;58:319-328.

-86 Sia D, Alsinet C, Newell P, Villanueva A: VEGF signaling in cancer treatment. Curr Pharm Des 2014;20:28342842

-87 Folkman J: Tumor angiogenesis: therapeutic implications. N Engl J Med 1971;285:1182-1186.

88 Kabbinavar F, Hurwitz HI, Fehrenbacher L, Meropol NJ, Novotny WF, Lieberman G, Griffing S, Bergsland E: Phase II, randomized trial comparing bevacizumab plus fluorouracil (FU)/leucovorin (LV) with FU/LV alone in patients with metastatic colorectal cancer. J Clin Oncol 2003;21:60-65.

89 Ling Y, Yang Y, Lu N, You QD, Wang S, Gao Y, Chen Y, Guo QL: Endostar, a novel recombinant human endostatin, exerts antiangiogenic effect via blocking VEGF-induced tyrosine phosphorylation of KDR/Flk-1 of endothelial cells. Biochem Biophys Res Commun 2007;361:79-84.

$>90$ Jayson GC, Kerbel R, Ellis LM, Harris AL: Antiangiogenic therapy in oncology: current status and future directions. Lancet 2016;388:518-529.

-91 Goel S, Wong AH, Jain RK: Vascular normalization as a therapeutic strategy for malignant and nonmalignant disease. Cold Spring Harb Perspect Med 2012;2:a006486.

$\$ 92$ Schmittnaegel M, Rigamonti N, Kadioglu E, Cassará A, WyserRmili C, Kiialainen A, Kienast Y, Mueller HJ, Ooi CH, Laoui D, De Palma M: Dual angiopoietin-2 and VEGFA inhibition elicits antitumor immunity that is enhanced by PD-1 checkpoint blockade. Sci Transl Med 2017;9.

-93 Christofk HR, Vander Heiden MG, Harris MH, Ramanathan A, Gerszten RE, Wei R, Fleming MD, Schreiber SL, Cantley LC: The M2 splice isoform of pyruvate kinase is important for cancer metabolism and tumourgrowth. Nature 2008;452:230-233.

$\$ 94$ Miles LA, Dahlberg CM, Plescia J, Felez J, Kato K, Plow EF: Role of cell-surface lysines in plasminogen binding to cells: identification of alpha-enolase as a candidate plasminogen receptor. Biochemistry 1991;30:1682-1691.

$\$ 95$ Marx J: Medicine. Cancer-suppressing enzyme adds a link to type 2 diabetes. Science 2005;310:1259.

$\$ 96$ Wu L, Zhou B, Oshiro-Rapley N, Li M, Paulo JA, Webster CM, Mou F, Kacergis MC, Talkowski ME, Carr CE, Gygi SP, Zheng B, Soukas AA: An Ancient, Unified Mechanism for Metformin Growth Inhibition in C. elegans and Cancer. Cell 2016;167:1705-1718.e13.

-97 Liu X, Romero IL, Litchfield LM, Lengyel E, Locasale JW: Metformin Targets Central Carbon Metabolism and Reveals Mitochondrial Requirements in Human Cancers. Cell Metab 2016;24:728-739.

$>98$ Qi C, Zhou Q, Li B, Yang Y, Cao L, Ye Y, Li J, Ding Y, Wang H, Wang J, He X, Zhang Q Lan T, Lee KK, Li W, Song $\mathrm{X}$, Zhou J, Yang X, Wang L: Glipizide, an antidiabetic drug, suppresses tumor growth and metastasis by inhibiting angiogenesis. Oncotarget 2014;5:9966-9979.

-99 Duan HF, Hu XW, Chen JL, Gao LH, Xi YY, Lu Y, Li JF, Zhao SR, Xu JJ, Chen HP, Chen W, Wu CT: Antitumor activities of TEM8-Fc: an engineered antibody-like molecule targeting tumor endothelial marker 8 J Natl Cancer Inst 2007;99:1551-1555.

100 Ohnuma K, Hatano R, Morimoto C: DPP4 in anti-tumor immunity: going beyond the enzyme. Nat Immunol 2015;16:791-792.

101 Deaglio S, Dwyer KM, Gao W, Friedman D, Usheva A, Erat A, Chen JF, Enjyoji K, Linden J, Oukka M, Kuchroo VK, Strom TB, Robson SC: Adenosine generation catalyzed by CD39 and CD73 expressed on regulatory T cells mediates immune suppression. J Exp Med 2007;204:1257-1265. 


\section{Cellular Physiology Cell Physiol Biochem 2018;47:441-457 \begin{tabular}{l|l|l} 
DOI: 10.1159/000489979 & O 2018 The Author(s). Published by S. Karger AG, Basel \\
www.karger.com/cpb
\end{tabular}}

Duan: Novel Therapeutic Strategies Based on Antitumor Immune System

102 Sun X, Wu Y, Gao W, Enjyoji K, Csizmadia E, Müller CE, Murakami T, Robson SC: CD39/ENTPD1 expression by CD4+Foxp3+ regulatory T cells promotes hepatic metastatic tumor growth in mice. Gastroenterology 2010;139:1030-1040.

-103 Mandapathil M, Hilldorfer B, Szczepanski MJ, Czystowska M, Szajnik M, Ren J, Lang S, Jackson EK, Gorelik E, Whiteside TL: Generation and accumulation of immunosuppressive adenosine by human CD4+CD25highFOXP3+ regulatory T cells. J Biol Chem 2010;285:7176-7186.

104 Sitkovsky MV, Kjaergaard J, Lukashev D, Ohta A: Hypoxia-adenosinergic immunosuppression: tumor protection by T regulatory cells and cancerous tissue hypoxia. Clin Cancer Res 2008;14:5947-5952.

105 Hatfield SM, Kjaergaard J, Lukashev D, Schreiber TH, Belikoff B, Abbott R, Sethumadhavan S, Philbrook P, Ko K, Cannici R, Thayer M, Rodig S, Kutok JL, Jackson EK, Karger B, Podack ER, Ohta A, Sitkovsky MV: Immunological mechanisms of the antitumor effects of supplemental oxygenation. Sci Transl Med 2015; 7:277ra30.

106 Parajuli P, Singh SM: Alteration in IL-1 and arginase activity of tumor-associated macrophages: a role in the promotion of tumor growth. Cancer Lett 1996;107:249-256.

107 Shakoor N, Michalska M, Harris CA, Block JA: Drug-induced systemic lupus erythematosus associated with etanercept therapy. Lancet 2002;359:579-580.

108 Nash P, Kirkham B, Okada M, Rahman P, Combe B, Burmester GR, Adams DH, Kerr L, Lee C, Shuler CL, Genovese M; SPIRIT-P2 Study Group: Ixekizumab for the treatment of patients with active psoriatic arthritis and an inadequate response to tumour necrosis factor inhibitors: results from the 24-week randomised, double-blind, placebo-controlled period of the SPIRIT-P2 phase 3 trial. Lancet 2017. pii: S0140-6736(17)31429-0.

109 Smolen JS, Beaulieu A, Rubbert-Roth A, Ramos-Remus C, Rovensky J, Alecock E, Woodworth T, Alten R; OPTION Investigators: Effect of interleukin- 6 receptor inhibition with tocilizumab in patients with rheumatoid arthritis (OPTION study): a double-blind, placebo-controlled, randomised trial. Lancet 2008;371:987-997.

110 Jochems C, Fantini M, Fernando RI, Kwilas AR, Donahue RN, Lepone LM, Grenga I, Kim YS, Brechbiel MW, Gulley JL, Madan RA, Heery CR, Hodge JW, Newton R, Schlom J, Tsang KY: The ID01 selective inhibitor epacadostat enhances dendritic cell immunogenicity and lytic ability of tumor antigen-specific T cells. Oncotarget 2016;7:37762-37772.

111 Kalgutkar AS, Crews BC, Rowlinson SW, Marnett AB, Kozak KR, Remmel RP, Marnett LJ: Biochemically based design of cyclooxygenase-2 (COX-2) inhibitors: facile conversion of nonsteroidal antiinflammatory drugs to potent and highly selective COX-2 inhibitors. Proc Natl Acad Sci U S A 2000;97:925-930.

112 Hsieh MJ, Lin CW, Chiou HL, Yang SF, Chen MK: Dehydroandrographolide, an iNOS inhibitor, extracted from Andrographis paniculata (Burm.f.) Nees, induces autophagy in human oral cancer cells. Oncotarget 2015;6:30831-30849.

113 Dvorak HF: Tumors: wounds that do not heal. Similarities between tumor stroma generation and wound healing. N Engl J Med 1986;315:1650-1659.

114 L.A.G. Ries, D. Melbert, M. Krapcho, A. Mariotto, B.A. Miller, E.J. Feuer, L. Clegg, M.J. Horner, N. Howlader, M.P. Eisner, M. Reichman, B.K: Edwards (Eds.), SEER Cancer Statistics Review, 1975-2004, National Cancer Institute, Bethesda, MD. Available from: , based on November 2006 SEER data submission, posted to the SEER web site, 2007.

115 Anand P, Sundaram C, Jhurani S, Kunnumakkara AB, Aggarwal BB: Curcumin and cancer: an "old-age" disease with an "age-old" solution. Cancer Lett 2008;267:133-164.

116 Cao L, Liu X, Lin EJ, Wang C, Choi EY, Riban V, Lin B, During MJ: Environmental and genetic activation of a brain-adipocyte BDNF/leptin axis causes cancer remission and inhibition. Cell 2010;142:52-64.

117 Sachlos E, Risueño RM, Laronde S, Shapovalova Z, Lee JH, Russell J, Malig M, McNicol JD, Fiebig-Comyn A, Graham M, Levadoux-Martin M, Lee JB, Giacomelli AO, Hassell JA, Fischer-Russell D, Trus MR, Foley R, Leber B, Xenocostas A, Brown ED, Collins TJ, Bhatia M: Identification of drugs including a dopamine receptor antagonist that selectively target cancer stem cells. Cell 2012;149:1284-1297.

118 Choi SH, Tamura K, Khajuria RK, Bhere D, Nesterenko I, Lawler J, Shah K: Antiangiogenic variant of TSP-1 targets tumor cells in glioblastomas. Mol Ther 2015;23:235-243. 